\title{
Pengaruh Yoga Prenatal terhadap Outcome Persalinan
}

\section{The Influence Of Prenatal Yoga On The Maternity Outcomes}

\author{
Nita Evrianasari ${ }^{1}$, Yuli Yantina ${ }^{2}$ \\ Fakultas Kedokteran, Universitas Malahayati, Indonesia
}

\section{ARTICLE INFO}

\section{Article history}

Received date

31 Jan 2020

Revised date

13 Mar 2020

09 Apr 2020

Accepted date

04 August 2020

\section{Keywords:}

Labor pain;

Maternity outcome;

Prenatal yoga;

Ruptur perineum.

\section{Kata kunci:}

Nyeri persalinan; Outcome Persalinan; Yoga prenatal; Ruptur perineum.

\author{
ABSTRACT/ ABSTRAK
}

Psychological problems experienced by women in childbirth difficulties are anxiety $(52 \%)$ and doubt about their ability to cope with pain (43\%). A study found $66,6 \%$ of prenatal yoga can improve the physical and psychological readiness of maternity mothers. Prenatal Yoga is a type of body, mind, and mental exercise that is one of the goals of training hip and surrounding muscles, to become stronger and elastic. The purpose of this study is to determine the influence of Prenatal Yoga on the outcome of childbirth which includes: Labor pain at a time of 1, long as 2, and Rupture Perinium on labor in BPM Yuli Artika SST Pesawaran. The type in this study is quantitative with the design of the experimental Quasi (pseudo experiment) research with the draft posttest only non-equivalent Control Group Design. The sample is a pregnant trimester III who meets the criteria of 60 respondents. Results showed that there is a prenatal yoga influence on pain during childbirth at the BPS Yuli Artika SST The participants were shown with the p-value $0,000(<0,05)$, there is a prenatal yoga influence to a long time II childbirth at BPS Yuli Artika SST Pesawaran with p-value 0,000 $(<0,05)$ and there is a prenatal yoga influence against the perineum tendon rupture at the BPS Yuli Artika SST Pesawaran with p-value $0,000(<0,05)$. Given the many benefits of yoga for maternity mothers then prenatal yoga can be used as one of routine obstetrics that is given to pregnant during antenatal care, especially for BPS Yuli Artika Pesawaran.
Permasalahan psikologis yang dialami ibu bersalin dalam menghadapi persalinan yaitu cemas $(52 \%)$ dan ragu akan kemampuannya mengatasi rasa nyeri $(43 \%)$. Sebuah penelitian mendapatkan hasil $66,6 \%$ yoga prenatal dapat meningkatkan kesiapan fisik dan psikologis ibu bersalin. Yoga prenatal adalah jenis olahraga tubuh, pikiran dan mental yang salah satu tujuannya melatih otot panggul dan sekitarnya, agar menjadi lebih kuat dan elastis. Tujuan dari penelitian ini adalah untuk mengetahui pengaruh yoga prenatal terhadap outcome persalinan yang meliputi: nyeri persalinan kala 1, lama kala 2, dan Ruptur perinium pada ibu bersalin di BPM Yuli Artika Pesawaran. Jenis penelitian kuantitatif dengan desain penelitian Quasi Eksperimen (Eksperimen semu) dengan rancangan postest only non-equivalent control Group Disign. Sampel adalah ibu hamiltrimester III yang memenuhi kriteria dengan jumlah 60 responden. Hasil penelitian menunjukkan ada pengaruh prenatal yoga terhadap nyeri kala I persalinan di BPS Yuli Artika SST pesawaran ditunjukkan dengan p-value $0,000(<0,05)$, ada pengaruh prenatal yoga terhadap lama kala II persalinan di BPS Yuli Artika SST pesawaran dengan $p$-value $0,000(<0,05)$ dan ada pengaruh prenatal yoga terhadap ruptur perineum di BPS Yuli Artika SST pesawaran dengan p-value $0,000(<0,05)$. Mengingat banyaknya manfaat yoga bagi ibu bersalin maka disaran kan prenatal yoga ini dapat dijadikan salah satu asuhan kebidanan rutin yang diberikan pada ibu hamil pada saat antenatal care khususnya bagi BPS Yuli Artika Pesawaran.

Corresponding Author:

Nita Evrianasari ${ }^{1}$, Yuli Yantina ${ }^{2}$

Fakultas Kedokteran, Universitas Malahayati, Indonesia

Email: ${ }^{1}$ nita.nuninosa@gmail.com, ${ }^{2}$ yantina.yuli@yahoo.co.id

\section{PENDAHULUAN}

Setiap perempuan menginginkan persalinannya berjalan lancar, bebas rasa nyeri dan minim trauma. Faktor yang berperan penting dalam proses persalinan yaitu kekuatan mendorong janin keluar meliputi his (kekuatan uterus) dan kontraksi otot dinding perut. Kondisi psikologis dapat berpengaruh terhadap tenaga ibu dan kelancaran proses persalinan. Walaupun $97 \%$ 
persalinan adalah persalinan fisiologis, kecemasan dalam persalinan dapat menimbulkan ketegangan otot-otot polos dan pembuluh darah, sehingga terjadi kekakuan serviks dan hipoksia pada rahim yang menyebabkan impuls nyeri bertambah banyak, impuls nyeri melalui thaloma limbic ke korteks serebri dari akibat menambah rasa takut, sehingga kontraksi rahim berkurang. Hal ini mengakibatkan persalinan membutuhkan waktu yang lama dan mungkin membutuhkan alat bantu bahkan operasi Caesar (Wahyuni,S, 2010)

Peningkatan beban psikologis pada ibu dapat menimbulkan permasalahan terhadap kualitas janin yang dikandung dan komplikasi yang menyertai proses persalinan ibu. Pencegahan dengan beberapa metode diperlukan untuk meringankan dan mempersiapkan ibu dalam menjaga kehamilan dan proses persalinannya. Pencegahan komplikasi persalinan bertujuan untuk membuat ibu dan bayi baru lahir dapat memperoleh derajat kesehatan yang tinggi dan terhindar dari berbagi ancaman dan fungsi reproduksi. Oleh karena itu keseimbangan tubuh dan pikiran harus selalu terpelihara untuk menciptakan pikiran tenang dan nyaman serta keduanya bisa bekerja seimbang, sehingga akan mengarah pada kehamilan dan persalinan yang tenang dan membahagiakan. Alternatif terapi yang dibutuhkan dalam menghadapi persalinan salah satunya adalah dengan melakukan meditasi/yoga (Shindu, 2014).

Permasalahan psikologis yang dialami ibu bersalin dalam menghadapi persalinan yaitu cemas $(52 \%)$ dan ragu akan kemampuannya mengatasi rasa nyeri (43\%). Kecemasan dan ketakutan yang dialami oleh ibu bersalin terutama primipara dapat memperpanjang durasi persalinan dan meningkatkan kejadian persalinan dengan tindakan, yaitu persalinan dengan seksio sesarea (OR 26,9 CI 95\%) dan vakum ekstraksi (OR 4,5 CI 95\%). Ibu yang pernah melahirkan dan mengalami cemas pada saat melahirkan merupakan saat-saat tidak menyenangkan dalam hidupnya (Hayati, 2018).

Yoga merupakan sebuah ilmu yang menjelaskan kaitan antara fisik, psikis dan spiritual manusia untuk mencapai kesehatan yang menyeluruh. Kata yoga berasal dari bahasa Sanskerta yang berarti union (penyatuan). Yoga terbentuk dari kebudayaan India kuno yang telah ada sejak lima ribu tahun lalu dan bertujuan untuk menyatukan atma (diri) dengan brahman (sang pencipta). Penyatuan diri akan membawa seseorang menuju penyatuan dengan Ilahi, semakin seseorang mengenal dirinya semakin ia mengenal sang penciptanya maka yoga sangan bermanfaat untuk dilakukan selama kehamilan, berlatih yoga selama kehamilan dapat menyebabkan ketenangan jiwa yang dibutuhkan oleh ibu hamil (Shindu, 2009).

Terdapat banyak aliran dari yoga, tetapi yang paling banyak dipraktikkan saat ini (terutama di dunia Barat) adalah Hatha yoga. Secara tradisional, Hatha yoga adalah sebuah jenis yoga yang memfokuskan praktiknya pada asana (postur yoga/ teknik penguasaan tubuh), pranayama (teknik penguasaan napas), bandha (teknik penguncian energi), mudra (teknik pengendalian energi), serta kriya (teknik pembersihan tubuh). Pada dasarnya berbagai macam postur yoga yang disertai dengan cara bernapas yang benar, dipercaya dapat memberikan banyak manfaat secara fisik, mental dan spiritual (Shindu, 2009).

Sebuah penelitian mendapatkan hasil sebagian besar responden yang melakukan senam yoga teratur mempunyai kesiapan fisik dan psikologis siap sebanyak 22 responden dan sebagian besar responden yang melakukan senam yoga tidak teratur mempunyai kesiapan fisik dan psikologis kurang siap sebanyak 11 responden. Hasil uji statistik dengan Chi-Square dengan $\alpha<0,05$ didapatkan $p$-value $=0,000$ berarti bahwa ada hubungan yang bermakna antara senam yoga ibu hamil dengan kesiapan fisik dan psikologis (Wati, 2018).

Beberapa studi tentang efek preventif dan terapeutik dari prenatal yoga telah dilaporkan dalam beberapa tahun terakhir dalam penelitian systematic review yang dilakukan oleh Kawanishi Y (2015) dari 54 kutipan ditemukan sejumlah delapan studi (10 laporan) dimasukkan dalam analisis akhirdidapatkan hasil pada wanita hamil yang sehat, terdapat peningkatan yang signifikan dalam menurunkan nyeri persalinan dan kepuasan saat melahirkan, durasi persalinan, tingkat stres yang dirasakan selama kehamilan, tingkat kecemasan, depresi, pengalaman yang berhubungan dengan kehamilan, kualitas hidup, dan hubungan interpersonal dibandingkan dengan yang ada di kelompok kontrol (Kawanishi Y, 2018).

Penelitian lain dilakukan oleh Chethana dkk (2018) menunjukkan hasil Kebutuhan induksi persalinan dan analgesik serta persalinan seksio sesarea secara signifikan lebih sedikit, kala I persalinan lebih cepat dan toleransi rasa sakit lebih baik

Selain itu, penelitian yang dilakukan Setyowati, dkk (2017) mendapatkan hasil bahwa ibu hamil yang mengikuti latihan yoga secara teratur selama kehamilan dapat mengurangi ternjadinya rupture perineum. 
Maka tujuan dari penelitian ini adalah untuk mengetahui pengaruh yoga prenatal terhadap outcome persalinan yang meliputi: nyeri persalinan kala 1, lama kala 2, dan Ruptur perinium pada ibu bersalin di BPM Yuli Artika Pesawaran.

\section{METODE}

Jenis penelitian ini adalah kuantitatif dengan desain penelitian Quasi Eksperimen (Eksperimen semu) dengan rancangan post-test only non-equivalent control group design. Sampel adalah ibu hamil trimester III yang memenuhi kriteria dengan jumlah 60 responden, sampel diambil dengan menggunakan teknik purposive sampling, dengan kriteria inklusi: 1 . Ibu hamil normal 2. Bersedia menjadi responden dan kriteria eksklusi: 1) ibu hamil normal dengan rencana persalinan SC 2) Ibu hamil yang melakukan yoga $<4$ kali.

Intervensi kelompok eksperimen dilakukan sejak responden memasuki trimester III hingga responden akan bersalin. Sedangkan pada kelompok kontrol asuhan dilakukan sesuai dengan standar di BPM Yuli Artika. Pada penelitian ini alat pengumpul data yang di gunakan adalah Numeric Rating Scale untuk mengetahui nyeri persalinan kala I dan lembar observasi berdasarkan partograf untuk mengetahui lama persalinan kala II dan ruptur perineum. Analisa data pada penelitian ini menggunakan uji korelasi T-tes Independen, dengan bantuan software computer.

Penelitian ini telah melewati kaji etik dan memperoleh Keterangan Kelaikan Etik (Ethical Clearance) dengan Nomor 319/EC/KEPUNMAL/I/2019 oleh Komisi Ettik Penelitian Kesehatan, Universitas Malahayati.

\section{HASIL}

Berdasarkan hasil penelitian didapatkan karakteristik responden dalam penelitian ini adalah rata-rata usia ibu hamil berkisar 20-30 tahun, dengan umur kehamilan responden saat persalinan aterem, paritas berkisar 1-5, dan berat bayi lahir berkisar 2500-4000 gram.

\section{Uji Normalitas}

Uji normalitas data skala nyeri kala 1 , dan lama kala II pada kelompok yoga maupun tidak yoga menunjukkan distibusi normal ditunjukkan dengan $p$-value masing-masing: nyeri kala 1 kelompok yoga 0,101 dan kelompok tidak yoga 0,046 , lama kala II kelompok yoga 0,364 dan kelompok tidak yoga $0,720(<0,05)$ sedangkan pada data skala rupture perineum didapatkan hasil $p$-value pada kelompok yoga 0,001 dan dan pada kelompok yang tidak yoga 0,024 kurang dari 0,05 yang artinya distribusi data tidak normal sehingga uji statistik yang digunakan adalah Uji Mann-Whitney.

\section{Tabel 1. Distribusi Frekuensi Rata-rata Nyeri Kala I pada Ibu yang Melakukan Yoga dan Nyeri Kala I pada Ibu yang Tidak Melakukan Yoga

\begin{tabular}{lccrrrr}
\hline Variabel & Kategori & n & Mean & SD & Min & Max \\
\hline Nyeri & Yoga & 30 & 3,80 & 1,031 & 2 & 6 \\
\cline { 2 - 7 } Kala I & Tidak Yoga & 30 & 6,47 & 0,973 & 5 & 8 \\
\hline
\end{tabular}

Berdasarkan tabel 1 diketahui bahwa dari 30 responden diperoleh hasil nilai mean atau nilai rata-rata nyeri kala I pada ibu yang melalukan yoga sebesar 3,80 , dengan standar deviasi sebesar 1,031 , hasil skala nyeri terendah atau hasil skala nyeri minimal yaitu sebesar 2 dan hasil skala nyeri maksimal yaitu sebesar 6 . Sedangkan hasil nilai mean atau nilai rata-rata nyeri kala I pada ibu yang tidak melalukan yoga sebesar 6,47, dengan standar deviasi sebesar 0,973 , hasil skala nyeri terendah atau hasil skala nyeri minimal yaitu sebesar 5 dan hasil skala nyeri maksimal yaitu sebesar 8 .

Tabel 2. Distribusi Frekuensi Rata-rata Lama Kala II pada Ibu yang Melakukan Yoga dan Lama Kala II pada Ibu yang Tidak Melakukan Yoga

\begin{tabular}{lccccrr}
\hline Variabel & Kategori & n & Mean & SD & Min & Max \\
\hline Lama & Yoga & 30 & 15,67 & 7,626 & 5 & 30 \\
\cline { 2 - 7 } Kala II & Tidak Yoga & 30 & 33,07 & 19,309 & 5 & 100 \\
\hline
\end{tabular}

Berdasarkan tabel 2 diketahui bahwa dari 30 responden diperoleh hasil nilai mean atau nilai rata-rata lama kala II pada ibu yang melakukan yoga sebesar 15,67 menit, dengan standar deviasi sebesar 7,626, hasil lama kala II terendah atau hasil lama kala II minimal yaitu sebesar 5 dan 
hasil lama kala II maksimal yaitu sebesar 30 . Sedangkan hasil nilai mean atau nilai rata-rata kala kala II pada ibu yang tidak melalukan yoga sebesar 33,07 menit, dengan standar deviasi sebesar 19,309, hasil lama kala II terendah atau hasil lama kala II minimal yaitu sebesar 5 dan hasil skala nyeri maksimal yaitu sebesar 100 .

Tabel 3. Distribusi Frekuensi Rata-rata Rupture Perineum pada Ibu yang Melakukan Yoga dan Rupture Perineum pada Ibu yang Tidak Melakukan Yoga

\begin{tabular}{lccrrrr}
\hline Variabel & Kategori & n & Mean & SD & Min & Max \\
\hline Rupture & Yoga & 30 & 1,33 & 0,959 & 0 & 2 \\
\cline { 2 - 7 } Perineum & Tidak Yoga & 30 & 2,13 & 0,860 & 0 & 3 \\
\hline
\end{tabular}

Berdasarkan tabel 3 diketahui bahwa dari 30 responden diperoleh hasil nilai mean atau nilai rata-rata rupture perineum pada ibu yang melalukan yoga sebesar 1,33, dengan standar deviasi sebesar 0,959 , hasil rupture perineum terendah yaitu sebesar 0 (tidak rupture) dan hasil rupture perineum maksimal yaitu sebesar 2 .
Sedangkan hasil nilai mean atau nilai rata-rata rupture perineum pada ibu yang tidak melalukan yoga sebesar 2,13, dengan standar deviasi sebesar 0,860 , hasil rupture perineum terendah yaitu sebesar 0 (tidak rupture) dan hasil rupture perineum maksimal yaitu sebesar 3 .

Tabel 4. Analisa Bivariat Pengaruh Yoga Prenatal terhadap Outcome Persalinan

\begin{tabular}{|c|c|c|c|c|c|}
\hline Variabel & Kategori & Mean & SD & $\mathbf{T}$ & p-value \\
\hline \multirow[t]{2}{*}{ Nyeri Kala I } & Yoga & 3,80 & 1,031 & \multirow{2}{*}{$-10,304$} & \multirow{2}{*}{0,000} \\
\hline & Tidak Yoga & 6,47 & 0,973 & & \\
\hline \multirow[t]{2}{*}{ Lama Kala II } & Yoga & 15,67 & 7,626 & \multirow{2}{*}{$-4,591$} & \multirow{2}{*}{0,000} \\
\hline & Tidak Yoga & 33,07 & 19,309 & & \\
\hline \multirow{2}{*}{$\begin{array}{l}\text { Rupture } \\
\text { Perineum }\end{array}$} & Yoga & 1,33 & 0,959 & \multirow{2}{*}{$-3,401$} & \multirow{2}{*}{0,001} \\
\hline & Tidak Yoga & 2,13 & 0,860 & & \\
\hline
\end{tabular}

Berdasarkan tabel 4 diketahui hasil uji $\mathrm{t}$ didapat pada semua variabel (Nyeri Kala I, Lama Kala II, Rupture Perineum) didapat $p$-value $0,000<$ alpha $(0,05)$ artinya ho ditolak dan ha diterima. Pada variabel nyeri kala I ibu yang melakukan yoga rata-rata terjadi pada skala nyeri 3 sedangkan pada ibu yang tidak melakukan yoga rata-rata terjadi pada skala nyeri 6 . Pada variabel lama kala II ibu yang melakukan yoga rata-rata terjadi dalam durasi 15 menit sedangkan pada ibu yang tidak melakukan yoga rata-rata terjadi dalam durasi 33 menit. Pada variabel rupture perineum ibu yang melakukan yoga rata-rata terjadi rupture pada derajat 1 sedangkan pada ibu yang tidak melakukan yoga rata-rata terjadi rupture pada derajat 2. Maka dari itu dapat disimpulkan bahwa terdapat pengaruh yang signifikan dengan dilakukan nya prenatal yoga.

\section{PEMBAHASAN}

\section{Pengaruh Prenatal Yoga terhadap Nyeri Kala I}

Hasil uji statistik menunjukkan bahwa ada pengaruh yang signifikan prenatal yoga terhadap nyeri kala 1 persalinan denga p-value 0,000 $(>0,05)$, dengan rata-rata nyeri kala 1 pada kelompok dengan prenatal yoga adalah 3,80 yang berarti ibu masih merasakan nyeri akan tetapi masih dapat ditahan atau dikontrol atau masih dalam kategori nyeri ringan sedang pada kelompok responden yang tidak prenatal yoga skala nyeri kala 1 adalah 6,47 artinya rasa nyeri yang mengganggu dan memerlukan usaha untuk menahannya. Hasil penelitian ini sejalan dengan penelitian yang dilakukan oleh Marwa, dkk (2017). Menunjukkan hasil bahawa ada intensitas nyeri lebih rendah pada ibu yang melakukan yoga, dengan $p$-value 0,001 .

Proses persalinan dimulai dengan adanya penipisan dan pembukaan servik. Penipisan dan pembukaan merupakan akibat langsung dari kontraksi. Kontraksi akan menjadi lebih sering, lebih lama dan intensitasnya semakin kuat. Kontraksi uterus pada persalinan bersifat unik, mengingat kontraksi ini merupakan kontraksi otot fisiologis yang menimbulkan nyeri pada tubuh (Varney, 2008).

Yoga adalah sebuah intervensi didasarkan pada penyatuan antara pikiran dan tubuh serta salah satu metode non-farmakologis yang dapat digunakan untuk membantu pengurangan rasa sakitselama persalinan hal ini dikarenakan prenatal yoga dapat membantuwanita menjadi terbiasa dengan keadaan yang lebih natural dan posisi naluriah saat persalinan. Ketika kontraksi melebihi ambang rasa sakit, yoga menyediakan 
kesempatan untuk mengeksplorasi respons seseorang terhadap rasa sakitdan untuk mengembangkan strategi relaksasi dan penanggulangannya. Sehingga yoga bisa menjadi cara yang efektif untuk memberdayakan ibu selama persalinan dalam membantumencapai dan mempertahankan level optimal ambang nyeri (Chuntharapat, 2008).

Prenatal yoga membuat ibu lebih menguasai diri dan menikmati setiap proses persalinan sehingga nyeri persalinan dapat terabaikan. Hal ini menguatkan bukti bahwa latihan yoga prenatal dapat dijadikan terapi non farmokologis untuk asuhan nyeri persalinan yang minim efek samping (Jahdi, 2018).

Sebuah penelitian Randomized Control Trial (RCT) 2008 melibatkan 74 penelitian yang dilakukan untuk mengevaluasi efek dari program yoga prenatal pada nyeri persalinan dibandingkan dengan perawatan standar pada wanita primigravida di Thailand yang menerima perawatan antenatal teratur. Dengan intervensi enam sesi yoga dengan durasi satu jam pada setiap sesi pada usia kehamilan 26 dan 37 minggu. Nyeri persalinan diukur dengan skala analog visual 100 poin dan perilaku nyeri yang diamati oleh peneliti selama persalinan diukur dengan skor mulai dari 5 hingga 15 (skor yang lebih rendah menunjukkan lebih banyak nyeri yang dirasakan). Peneliti mengumpulkan data pada tiga interval dua jam setelah persalinan memasuki fase aktif. Kelompok yoga memiliki skor nyeri yang sedikit lebih rendah dan skor perilaku nyeri yang sedikit lebih rendah (Byrne, $\mathrm{R}, 2018$ ).

Hasil penelitian ini sejalan dengan penelelitian Marwa (2017) yang menyatakan bahwa ada perbedaan skala nyeri kala I primigravida yang senam hamil dan yoga kehamilan dengan nilai $p$-value $0,001 \quad(<0,05)$. Primigravida yang mengikuti senam hamil memiliki intensitas nyeri berat, sedangkan primigravida yang mengikuti yoga kehamilan memiliki intensitas nyeri sedang. Rendahnya skala nyeri persalinan kala I pada kelompok yoga kehamilan dikarenakan pada prinsip yoga kehamilan lebih ditekankan pada teknik pernafasan yang benar, relaksasi dan meditasi tubuh dan pikiran ibu, sehingga ibu lebih mampu mengatasi nyeri yang dirasakan. Pernafasan terkontrol merupakan salah satu teknik nonfarmakologi yang dapat membantu mengurangi persepsi nyeri dan biasanya aman.

Penelitian yang dilakukan oleh Marwa (2017) menggunakan desain penelitian kohort Prospektif dengan kriteria responden telah mengikuti senam dan yoga kehamilan secara rutin sejak TM II tetapi tidak ditemukan keterangan durasi serta sesi yang harus diikuti. Hasil yang didapat nilai minimal nyeri persalinan kala I adalah 4 dan nilai maksimal adalah 8 . Sementara pada penelitian ini dengan desain penelitian quasi eksperimen dengan rancangan postest only non-equivalent control Group Design didapatkan, dimana setiap responden dengan usia kehamilan memasuki 32 minggu melakukan yoga prenatal minimal 4 kali, didapatkan hasil bahwa sekala nyeri tertinggi adalah 6 dan sekala nyeri terendah adalah 2 . Secara umum karakteristik responden kedua panlitian adalah sama, perbedaannya yaitu pada penelitian Marwa (2017) membatasi responden pada primigravida, hal ini memungkinkan adanya perbedaan skala nyeri minimal dan maksimal pada kedua penelitian.

\section{Pengaruh Prenatal Yoga terhadap Lama Kala II}

Hasil uji statistik menunjukkan bahwa ada pengaruh yang signifikan prenatal yoga terhadap nyeri kala 1 persalinan denga p-value 0,000 $(>0,05)$, dengan rata-rata lama kala II pada kelompok yoga adalah 15, 67 menit dan pada kelompok yang tidak yoga adalah 33,07 menit, dan maksimal lama kala 2 pada kelopok yoga adalah 30 menit sedangkan pada kelompok yang tidak yoga adalah 100 menit, dari pernyataan tersebut dapat terlihat bahwa ibu yang melakukan prenatal yoga lama kala II saat persalinannya jauh lebih singkat dibandingkan dengan ibu yang tidak melakukan prenatal yoga.

Yoga prenatal bermanfaat untuk melatih dan menguasai teknik pernafasan pada proses persalinan. Latihan tekhnik pernafasan berguna untuk melatih ketegangan, memperlancar peredaran darah dan memenuhi kebutuhan oksigen bagi ibu dan janin. Latihan yoga prenatal juga berfungsi untuk memperkuat dan menjaga elastisitas otot dinding perut, ligamen, otot dasar panggul, dan otot di bagian dalam pinggul sehingga proses persalinan dapat berjalan cepat dan aman, selain itu latihan yoga juga berpengaruh pada persendian yang memiliki peran dalam mempercepat proses persalinan (Treacy, 2016).

Praktik hatha yoga bagi ibu hamil secara umum tidak jauh berbeda dengan praktik yoga bagi orang dewasa lainnya. Pada dasarnya, prenatal yoga merupakan modifikasi dari yoga klasik yang telah disesuaikan dengan kondisi fisik wanita hamil yang dilakukan dengan intensitas yang lebih lembut dan perlahan. Modifikasi dan perhatian khusus saat berlatih prenatal yoga sangat diperlukan untuk 
menghindarkan calon ibu dari cedera, dan juga demi kenyaman dan keamanan. Yoga dapat melatih otot perineum (otot dasar panggul) yang berfungsi sebagai otot kelahiran; membuatnya lebih kuat dan elastis sehingga mempermudah proses kelahiran, yoga mengurangi kecemasan dan mempersiapkan mental sang ibu untuk menghadapi persalinan. Yoga mengajarkan teknik-tiknik penguasaan tubuh dan menekankan bahwa otot yang tegang tidak akan membantu saat persalinan. Saat tubuh tegang, pikiran akan tegang sehigga akan cenderung menahan nafas. Dengan berlatih yoga untuk kehamilan secara teratur, akan mempu mengenali munculnya setiap ketegangan tersebut dan menjaga agar suasana pikiran tetap relaks, menjaga napas tetap dalam, yang pada akhirnya akhirnya membuat otot tubuh juga lemas dan relaks sehingga mempermudah proses kelahiran (Shindu, 2009).

Selain itu latihan yoga prenatal dapat memperkuat kuat otot sehingga ibu merasa rileks dengan adanya tambahan energi yang dapat mempengaruhi proses persalinan. Dengan adanya penguatan dan flaksibilitas otot perineum, vagina, sprigter ani, dan saluran kemih serta diikuti dengan penambahan diameter pelvik yang dihasilkan dari latihan yoga rutin sehingga latihan yoga dapat memfasilitasi persalinan minim trauma dan menurunkan durasi disetiap fase persalinan (Jahdi, 2017).

Penelitian ini sejalan dengan penelitian Dewi (2016) yang mendapatkan hasil bahwa yoga prenatal memperpendek durasi kala II persalinan dengan nilai $p$-value $<0,05$. Rata-rata lama kala II pada ibu dengan yoga adalah 0,25 jam dan rata-rata lama kala II pada ibu yang tidak melakukan yoga prenatal adalah 1,7 jam. Mempersingkat durasi kala II akan membantu mengurangi kejadian persalinan lama, mengurangi stres dan cidera selama persalinan.

Hasil pada penelitian ini juga sejalan dengan penelitian yang dilakukan oleh Setyowati, dkk (2017) dimana didapatkan hasil durasi rata-rata persalinan tahap kedua pada kelompok eksperimen adalah 25,32 menit dan kelompok kontrol 43,44 menit dengan p-value $0,00 \quad(<0,05)$, yang menunjukkan bahwa ada perbedaan yang signifikan dalam durasi tahap kedua. persalinan antara kedua kelompok.

Pada penelitian Setyowati, dkk (2017) jenis yoga prenatal yang dilakukan sama dengan penelitian ini, begitupun dengan karakteristik responden dan waktu pelaksanan yoga prenatal sama yang dimulai sejak usia kehamilan 32 minggu. Tetapi terdapat perbedaan pada intervensi yang dilakukan yaitu durasi yoga prenatal, dimana pada penelitian Setyowati, dkk
(2017) dilakukan selama 30 menit, sedangkan pada penelitian ini dilakukan selama 1 jam. Hasil penelitian juga menunjukkan perbedaan dimana waktu minimal dan maksimal durasi persalinan lebih rendah pada penelitian ini.

\section{Pengaruh Prenatal Yoga terhadap Rupture Perineum}

Hasil uji statistik menunjukkan bahwa ada pengaruh yang signifikan prenatal yoga terhadap nyeri kala 1 persalinan denga $p$-value 0,001 $(>0,05)$, dengan rata-rata rupture perineum pada kelompok prenatal yoga adalah derajat 1 dan kelompok yang tidak melakukan prenatal yoga adalah derajat 2 , berdasarkan hasil tersebut dapat disimpulkan bahwa ibu yang melakukan prenatal yoga hanya mengalami rupture derajat 1 yang artinya ibu tidak membutuhkan intervensi berupa penjahitan berbeda halnya dengan kelompok yang tidak melakukan prenatal yoga rata-rata mengajami rupture perineum derajat 2 yang mebutuh kan penjahitan untuk menghidari pendarahan dan infeksi.

Hasil pada penelitian ini sejalan dengan penelitian yang dilakukan oleh Setyowati, dkk (2017) dimana didapatkan hasil terdapat perbedaan yang signifikan $p$-value 0,000 pada rupture perineum antara kelompok yang melakukan yoga dan kelompok yang tidak melakukan yoga.

Manfaat prenatal yoga salah satunya memperkuat dan mepertahankan elastisitas otot dinding perut, ligamentum, otot dasar panggul, otot paha bagian dalam dengan demikian proses persalinan dapat dikuasai. Proses relaksasi akan sempurna dengan melakukan kontrasi dan relaksasi yang dperlukan untuk mengatasi ketegangan atau atau rasa saki saat proses persalinan salah satu latihan yang menguatkan dan mempertahankan elastisitas adalah latihan menguatkan otot dasar panggul yang gunanya untuk melemaskan otot dasar panggul yang kuat dalam keadaan yang santai pada saat mengejan otot akan mengendur secara aktif sehingga kepala bayi akan keluar dengan mudah dengan demikian akan memperlancar dalam proses persalinan dan mengurang resiko terjadinya rupture perineum (Treacy, 2016).

Selain itu latihan yoga prenatal dapat memperkuat kuat otot sehingga ibu merasa rileks dengan adanya tambahan energi yang dapat mempengaruhi proses persalinan. Dengan adanya penguatan dan fleksibilitas otot perineum, vagina, sprigter ani, dan saluran kemih serta diikuti dengan penambahan diameter pelvik yang dihasilkan dari latihan yoga rutin sehingga 
latihan yoga dapat memfasilitasi persalinan minim trauma dan menurunkan durasi disetiap fase persalinan (Jahdi, 2017).

Yoga prenatal merupakan salah satu cara untuk membantu menjaga perineum tetap utuh. Latihan yoga prenatal membantu menjaga perineum kuat dan fleksibel. Latihan ini bermanfaat memperkuat otot tetapi juga mengajarkan cara untuk mengendurkannya

\section{DAFTAR PUSTAKA}

Byrne, R., \& Dennard, E. (2018). Effects of Prenatal Yoga on Labor Pain. American family physician, 98(1), 49-49.

Chethana, B., Raghunandan, C., Saili, A., Mondal, S., \& Saxena, P. (2018). Prenatal Yoga: Effects on Alleviation of Labor Pain and Birth Outcomes. Journal of alternative and complementary medicine (New York, $N Y$ ).

https://www.ncbi.nlm.nih.gov/pubmed/301 60530

Chuntharapat, S., Petpichetchian, W., \& Hatthakit, U. (2008). Yoga during pregnancy: effects on maternal comfort, labor pain and birth outcomes. Complementary therapies in clinical practice, 14(2), 105-115.

Dewi, R. S., Soepardan, S., Suwondo, A., \& Sari, N. (2016). Pregnant yoga shorten the first and second stage of prolong labor in primigravida. In ASEAN/Asian Academic Society International Conference Proceeding Series.

Hayati, F., Herman, R. B., \& Agus, M. (2018). Perbedaan Tingkat Kecemasan Ibu Bersalin di Puskesmas dengan di Bidan Praktik Mandiri dan Hubungannya dengan Lama Persalinan. Jurnal Kesehatan Andalas, 6(3), 564-571.

Jahdi, F., Sheikhan, F., Haghani, H., Sharifi, B., Ghaseminejad, A., Khodarahmian, M., \& Rouhana, N. (2017). Yoga during pregnancy: The effects on labor pain and delivery outcomes (A randomized controlled trial). Complementary therapies in clinical practice, 27, 1-4. http://www.sciencedirect.com/science/artic le/pii/S1744388116302316

Treacy, Karly. (2016). Prenatal Yoga: A Pelvic Floor Sequence for an Easier Labor+Delivery. https://www.yogajournal.com/lifestyle/pre natal-yoga-pelvic-floor-sequence-easierlabor-

\section{SIMPULAN}

Hasil penelitian menunjukkan bahwa yoga yang dilakukan selama 1 jam, dilakukan minimal 4 kali pada usia kehamilan memasuki trimester III dapat mengurangi nyeri persalinan kala I, mempercepat kala II dan mencegah rupture perineum.

delivery\#gid=ci020756aaf0312620\&pid=b ound-angle-pose

Kawanishi, Y., Hanley, S. J., Tabata, K., Nakagi, Y., Ito, T., Yoshioka, E., ... \& Saijo, Y. (2015). Effects of prenatal yoga: a systematic review of randomized controlled trials. [Nihon koshu eisei zasshi] Japanese journal of public health, 62(5), 221-231.

https://www.ncbi.nlm.nih.gov/pubmed/261 18705

Marwa, A. R., \& Maryani, T. (2017). Perbedaan Skala Nyeri Kala I Dan Durasi Kala Ii Persalinan Pada Primigravida Dengan Senam Dan Yoga Kegamilan. Karya Tulis Ilmiah. Politeknik Kesehatan Kemenkes Yogyakarta.

Setyowati, A., Suhartono, S., Ngadiyono, N., Pujiastuti, R. S. E., \& Dyah, D. (2017). Effect Of Yoga On Duration Of The Second Stage Of Labor And Perineal Rupture In Primigravida Mothers. Belitung Nursing Journal, 3(6), 702-706.

Sindhu, P. (2009). Yoga Untuk Kehamilan: Sehat, Bahagia\& Penuh Makna. Bandung: Qanita.

Shindu, Pujiastuti. (2014). Yoga untuk Kehamilan: Sehat, Bahagia, dan Penuh Makna. Bandung: Qanita.

Varney, Helen. (2008). Buku Ajar Asuhan Kebidanan Edisi 4. Jakarta: EGC.

Wahyuni, S. Siswanto, Y. (2010). Pengaruh Senam Hamil Terhadap Lamanya Persalinan Kala II Pada Ibu Hamil Primigravida di Kabupaten Semarang. Junal Gizi dan Kesehatan Ngudi Waluyo.Ungaran Semarang.

Wati, N. W. K. W., Supiyati, S., \& Jannah, K. (2018). Pengaruh Senam Yoga terhadap Kesiapan Fisik dan Psikologis dalam Menghadapi Persalinan di BPM Lasmitasari, S. ST. Jurnal Kedokteran dan Kesehatan, 14(1), 39-47. 